\title{
EDITORIAL
}

\section{Creative Legal Engineering}

Keywords: consent to be bound; multilateral environmental agreements; law of treaties.

Abstract: The article introduces innovative means by which states can express their consent to be bound by treaties. Such innovative means have been incorporated in some multilateral environmental agreements that were concluded in December 1999 and January 2000. It is discussed whether limits of law-making have been transgressed by the use of these innovative means as the law of treaties allegedly presupposes that states actually give their consent to new treaty obligations, take some active step to express their consent to such obligations and do so at a time that the obligations were in existence and were known to them.

\section{INTRODUCTION}

As a result of the essentially consensual nature of international law, a state cannot be bound by a treaty against its will. The catalogue of means by which a state can express its consent to be bound by a treaty, however, is open-ended. This is reflected in the 1969 Vienna Convention on the Law of Treaties' where it is stipulated that a state can express its consent to be bound by "signature, exchange of instruments constituting a treaty, ratification, acceptance, approval or accession, or by any other means if so agreed" (Article 11) (emphasis added). Such consent to be bound must also be expressed with respect to amendments of a treaty, including the addition and amendment of annexes to it (cf. Article 40).

In the 1980 s and 1990 s, 'other means' by which a state can express its consent to be bound were incorporated in several multilateral environmental agreements. ${ }^{2}$ A variety of special opt-in and opt-out procedures can be found in these agreements, including some that do not require ratification, acceptance or approval. These procedures have particularly been designed to facilitate the addition and amendment of annexes to such agreements or protocols to them. There is an established need for such procedures, because the annexes concerned are generally composed of lists of substances or states, forms, and other materials of a descriptive nature that is of a scientific, technical, procedural or administrative character. The pursuance of an effective global environmental policy requires

1. See 8 ILM 679 (1969).

2. See M. Fitzmaurice, Expression of Consent to be Bound by a Treaty as Developed in Certain Environmental Treaties, in J. Klabbers \& $\mathrm{R}$. Lefeber (Eds.), Essays on the Law of Treaties, A Collection of Essays in Honour of Bert Vierdag 59-80 (1998).

13 Leiden Journal of International Law 1-9 (2000)

(1) 2000 Kluwer Law International 
the speedy transposition of new scientific data in these annexes and this may not be achieved by the requirement to submit the addition or amendment of these annexes to lengthy traditional procedures of ratification, acceptance or approval.

However, even the addition and amendment of technical annexes to multilateral environmental agreements may have political, economic, or legal ramifications that require a cautious approach to the introduction in a treaty of innovative means of consent to be bound. Evidently, it is a negotiating state's responsibility to observe its internal procedures with respect to the conclusion of treaties, including the obligation to obtain parliamentary approval if that is required by such procedures. However, for a valid consent to be bound to be given under international law, it is not required that the consent to be bound to a treaty and, hence, to the addition and amendment of annexes to it, is made subject to the observance of internal procedures. Moreover, the special procedures for the expression of a state's consent to be bound do generally not apply to the treaty itself, but only to the addition and amendment of annexes to it. Multilateral environmental agreements themselves, including the addition of protocols and amendments to such treaties and protocols, are generally subject to ratification, acceptance, or approval. Hence, the use of 'other means' by which a state can express its consent to be bound to the addition and amendment of annexes will normally have been certified by states parties to a treaty, or a protocol to such treaty, in accordance with their internal procedures.

It may be said that the incorporation in multilateral environmental agreements of 'other means' by which a state can express its consent to be bound is evidence of the institutionalisation of these agreements. ${ }^{3}$ The conferences of parties established by multilateral environmental agreements resemble more and more plenary organs of international organisations; and multilateral environmental agreements more and more resemble constitutions of international organisations that permit plenary organs to adopt binding decisions by consensus, or by majority vote if no consensus can be achieved. Yet, such decisions cannot change the 'constitution' of an 'international organisation', at least not without ratification, acceptance or approval.

The question arises whether the development of innovative 'other means' by which a state can express its consent to be bound has its limits. Given the consensual nature of treaties, it would seem that the law of treaties presupposes that states actually give their consent to new treaty obligations, take some active step to express their consent to such obligations and do so at a time that the obligations were in existence and were known to them. However, at some recent negotiations on multilateral environmental agreements, these inherent limits of law-making were, or were nearly, transgressed.

3. See also C. Brölmann, The Legal Nature of International Organisations and the Law of Treaties, 1 Austrian Yearbook of International and European Law (2000) (forthcoming). 


\section{1999 UN/ECE GöTeborg Protocol to ABate ACIDIFICATION, EUTROPHICATION AND GROUND-LEVEL OZONE}

On 30 November 1999, the 1999 Protocol to the 1979 UN/ECE Convention on Long-Range Transboundary Air Pollution to Abate Acidification, Eutrophication and Ground-Level Ozone (Multi-Effect and Multi-Pollutant Protocol or M\&M Protocol) was opened for signature. ${ }^{4}$ Amongst other basic obligations, states parties will have to control their annual emissions of certain polluting compounds in accordance with Annex II to the M\&M Protocol (Article 3). Annex II lists, for every state party, its emission levels of 1990, its emission ceilings for 2010 and its percentage emission reductions for 2010 for sulphur, nitrogen oxides, ammonia, and volatile organic compounds. It is evident that Annex II is the core of the M\&M Protocol.

The entry into force of amendments of all but two annexes is subject to an opt-out procedure (Article 13(4-5)), but Annex II is not among those. The entry into force of amendments of this Annex is subject to the same opt-in procedure as the entry into force of amendments of the M\&M Protocol itself (Article 13(3)). However, a special procedure applies to 'adjustments' to Annex II. This procedure permits a state party to the 1979 Convention on Long-Range Transboundary Air Pollution (LRTAP Convention) that is not listed in Annex II to be added to it, together with emission levels, emission ceilings, and percentage emission reductions (Article 13(1)). An adjustment to Annex II is adopted by consensus of the parties present at a session of the Executive Body of the LRTAP Convention and enters into force for all parties to the M\&M Protocol ninety days after its notification (Article 13(6)). This in itself remarkable adjustment procedure can also be found in other protocols to the LRTAP Convention. It has been designed to facilitate the accession to the M\&M Protocol of members of the UN Economic Commission for Europe that were not party to the LRTAP Convention at the time of the adoption of the text of the M\&M Protocol (e.g. Albania, Estonia, and Israel) or, for various other reasons, have not been listed in Annex II (e.g. Cyprus, Iceland, and Turkey). The accession of a state to the M\&M Protocol requires a substantive amendment of it, but such amendment does not directly affect the obligations of the other states parties and has therefore not been made subject to ratification, acceptance, or approval by those other states.

Remarkable is the position of Canada and the United States under the M\&M Protocol. At the time of the adoption of the text of the Protocol, these states were not in a position to put forward emission ceilings and percentage emission reductions for sulphur, nitrogen oxides, and volatile organic compounds. However, their names are already listed in Annex II which, furthermore, carry footnotes making clear that the incorporation of emission ceilings and percentage

4. See UN/ECE Doc. EB.AIR/1999/1 
emission reductions for these states will not be subject to the adjustment procedure. As for ammonia, these states have been completely exempted from the incorporation in Annex II of such ceilings and reductions (Article 3(10.b)). Although these states are obliged to submit the emission ceilings and percentage emission reductions to the Executive Body upon ratification, acceptance, approval, or accession (Article 3(11)), this amendment of Annex II will not be subject to a decision of the Executive Body. With respect to these states, the respective emission ceilings and percentage emissions reductions are thus not the outcome of multilateral negotiations, but simple unilateral commitments. In practice, it is said, this has also been the case for the other states listed in Annex II, but still. Although this privileged position of Canada and the United States did cause some commotion in the final round of the negotiations, it was eventually agreed to by the other negotiating states.

So far, we have come from consent to be bound by tacit consent (adjustment procedure) to no consent required (privileged position of Canada and the United States). The 'M\&M' negotiations are a good example that one (adjustment procedure) leads to another (privileged position of Canada and the United States) to a point to draw the line. This line was drawn when a proposed expansion of the scope of the adjustment procedure was under consideration. According to the proposal, "[a]ny Party may propose an adjustment to its obligations contained in annex II to the present Protocol on the basis of a significant change to the methods used for estimating its national emissions" (emphasis added). ${ }^{5}$ Since emission ceilings may become inappropriate as a result of technical improvements in the methodologies used to compile inventories of emissions, a light procedure was suggested to adjust emission ceilings and percentage emission reductions. Although designed to keep pace with technical progress, it would enable states parties to amend essential obligations by consensus and to do so without submission to the internal procedures that are applicable if these obligations would be amended for other reasons. Such a procedure would be prone to abuse if, for example, the executive of a state cannot meet its obligations under the M\&M Protocol and seeks to amend them without submitting them to parliamentary approval. On the advice of the Legal Drafting Group to limit the scope of the adjustment procedure to the purpose for which it has been designed, the proposed expansion of the adjustment procedure was eventually rejected.

5. See Art. 13(1) of the Preliminary Draft to Abate Acidification, Eutrophication and Ground-Level Ozone, UN Doc. EB/AIR/WG.5/1999/11. 


\section{1999 BASEL PROTOCOL ON LIABILITY AND COMPENSATION FOR Damage Resulting From the Transboundary MOVEMENTS OF HAZARDOUS WASTES AND THEIR DISPOSAL}

On 10 December 1999, the Fifth Conference of the Parties to the 1989 Basel Convention on the Control of Transboundary Movements of Hazardous Wastes and Their Disposal adopted the text of a protocol on liability and compensation (Liability Protocol). ${ }^{6}$ The day before, at a very late stage of the negotiations in the Legal Working Group, the negotiations threatened to collapse over the determination of the financial limits to the liability under the Liability Protocol. Pursuant to Article 12(1), the financial limits are to be specified in an annex to the Liability Protocol. Annex B provides that the financial limits shall be determined by domestic law and that these limits shall not be lower than the minimum amounts set forth in the annex. These minimum amounts vary with the tonnage of the shipments of waste and were the subject of a prolonged debate. Some delegations had serious difficulties with this system that does not take into account that the tonnage of a shipment and the hazardous properties of such shipment are often inversely related. The impasse was overcome by the incorporation in the Liability Protocol of a new provision that facilitates the amendment of the provision on minimum amounts. Article 23 of the Liability Protocol (Amendment of Annex B) says that "[a]t its sixth meeting, the Conference of the Parties to the Basel Convention may amend paragraph (2) of Annex B following the procedure set out in Article 18 of the Basel Convention" (para. 1) and that "[s]uch an amendment may be made before the Protocol enters into force" (para. 2). According to Article 18 of the Basel Convention (Adoption and Amendment of Annexes), "[e]xcept as may be otherwise provided in any protocol with respect to its annexes" (para. 1), annexes to the Basel Convention and its protocols as well as any amendments to them shall be proposed and adopted in accordance with the relevant provisions of the procedure for the amendment of the Basel Convention and its protocols (paras. 2 and 3). According to Article 17 (Amendment of the Convention), "[a]mendments to any protocol shall be adopted at a meeting of the Parties to the protocol in question" (para. 2). It is clear that Article 23 of the Liability Protocol deviates from Article 17(2) of the Convention as it permits the Conference of the Parties to the Basel Convention, instead of the Meeting of the Parties to the Liability Protocol, to adopt an amendment of Annex B. This is not an alarming finding as Article 18(2) of the Basel Convention envisages and permits such special procedures to be incorporated in protocols to the Convention.

However, it is necessary to examine the legal effect of Article 23 of the Protocol in detail, because it contains a puzzling second paragraph and is linked to a decision of the Sixth Conference of Parties that is scheduled to take place in

6. See Doc. UNEP/CHW.5/29 (1999), Annex III, at 99. 
Spring 2001. If the Liability Protocol enters into force before the Sixth Conference of the Parties takes place, the provision can produce its legal effect and will, notably, allow states parties to the Basel Convention that are not parties to the Liability Protocol to participate in the decision-making on the amendment of Annex B. Given the required number of instruments of ratification, acceptance, or approval, it is, however, not very likely that the Liability Protocol will have entered into force by the time the Sixth Conference of the Parties takes place. This was anticipated by the negotiating states that drafted the second paragraph of Article 23 of the Liability Protocol to accommodate such a situation. However, this provision, which together with the first paragraph circumvents Articles 18(2.a) and 17(2) of the Basel Convention, cannot have any legal effect before the Liability Protocol has entered into force.

In this case, it was the threat to the achievement of consensus over the Liability Protocol that prompted the negotiators to incorporate a creative provision in the Protocol. However, it is not free from legal difficulties and the question arises what to do at the Sixth Conference of the Parties if the Liability Protocol has not entered into force by that time. First, it could, of course, be argued that signature suffices to express consent to be bound to Article 23(2) of the Liability Protocol. Although this is not provided for in the Liability Protocol in so many words and deviates from the relevant provisions of the Protocol on consent to be bound to it (Article 27), it could be argued that this was the intention of the negotiating states in view of the nature of the provision (cf. Article 12 of the 1969 Vienna Convention on the Law of Treaties). Second, the Sixth Conference of the Parties could adopt a new protocol on liability and compensation with an amended version of Annex B, but this will affect the signatures as well as deposited instruments of ratification, acceptance, or approval of the protocol that was adopted on 10 December 1999. Third, and this would seem to be the better solution, the Sixth Conference of the Parties could adopt a recommendation on an amended version of Annex B that will be difficult to resist for the First Meeting of the Parties to the Liability Protocol to convert into a valid amendment of the Protocol.

\section{2000 Cartagena Protocol on Biosafety}

In the early hours of 29 January 2000, the First Extraordinary Conference of the Parties to the 1992 Convention on Biological Diversity, at a resumed session in Montreal, adopted the 2000 Cartagena Protocol on Biosafety. The Biosafety Protocol provides, inter alia, for a procedure of advance informed agreement with respect to the transboundary movement of living modified organisms (Article 7). There was agreement on the idea to list in an annex the living modified organisms that will not be subject to the advance informed agreement procedure. At the Conference, however, no agreement was in reach on the living modified 
organisms to be listed in such an annex. In spite of assurances that such annexes could be adopted in the future in accordance with the provisions of the Biodiversity Convention on the addition and amendment of annexes and in spite of proposals to create an empty annex and amend it later in accordance with such procedures (Article 30), the Conference agreed that the advance informed agreement procedure shall not apply to "living modified organisms identified in a decision of the Conference of the Parties serving as the meeting of the Parties to the Protocol" (Article 7(4)). Accordingly, any such identification of such living modified organisms changes the scope of the Biosafety Protocol and amounts to an amendment of the relevant scope provision of the Protocol, be it in combination with an annex or not.

The Biosafety Protocol is not an integral part of the Biodiversity Convention and may provide for other procedures for the amendment of the Protocol, and also for the addition and amendment of annexes to it. Evidently, the Conference of the Parties serving as the meeting of the parties to the Biosafety Protocol may decide to follow the procedure of Article 30 of the Biodiversity Convention, but Article 7(4) of the Biosafety Protocol does provide the legal basis to amend the Protocol by a simple decision. Unless otherwise provided in the decision itself, such decision is not subject to ratification, acceptance, or approval. Moreover, having regard to the rules of procedures of the Conference of the Parties, ${ }^{7}$ which in principle also apply to decisions adopted by the Conference of the Parties serving as the meeting of the parties (Article 29(5) of the Biosafety Protocol), decisions on matters of substance, with the exception of a few types of decisions that are not relevant to the matter under consideration, may be adopted by consensus, or a two-thirds majority vote if consensus cannot be achieved (Rule $40(1)$ ). Accordingly, in the absence of consensus, a state party may be bound by an amendment of the scope of the Protocol against its will. The innovative character of Article 7(4) was noted in the report of the Legal Drafting Group. It was, however, not brought to the attention of the plenary in such a manner that it could be taken into account as it could have unleashed unwanted discussions in the final day of already complicated negotiations. Parties that do not wish to use such light amendment procedures will have to insist on the use of Article 30 of the Biodiversity Convention on the addition and amendment of annexes and to secure that any decision on the basis of Article 7(4) is carefully drafted to that effect.

A similar, yet slightly different provision can be found in the article of the Biosafety Protocol dealing with the handling, transport, packaging, and identification of living modified organisms (Article 18). Especially the paragraph dealing with living modified organisms that are intended for direct use as food or feed, or for processing, is a hard-fought compromise (para. 2(a)). To avoid unwanted legal complications, the Legal Drafting Group was not allowed to touch

7. See UN Doc. UNEP/CBD/COP/1/17 (1994), at 70. 
the final version of this paragraph that was negotiated in the final hours of the negotiations. The conflict came to a head on the documentation that should accompany a shipment of these living modified organisms, in particular the specification of their identity and unique identification. It was finally agreed that documentation accompanying a shipment of these living modified organisms must clearly identify that the shipment "may contain" such living modified organisms. Since time was running out and no agreement was in sight, it was further agreed that the Conference of the Parties serving as the meeting of the parties to the Biosafety Protocol "shall take a decision on the detailed requirements for this purpose, including specification of their identity and any unique identification, no later than two years after the entry into force of this Protocol". Obviously, this is an obligation of conduct and absolutely no guarantee that such a decision will be taken, even though there will be strong political pressure to do so.

Another question concerns the legal status of such a decision. Of course, parties can insist that it should be a decision to amend the Biosafety Protocol in accordance with the provision of the Biodiversity Convention that deals with the amendment of the Biodiversity Convention and its protocols (Article 29), but other parties may want to oppose that as this is not what the Biosafety Protocol necessarily requires. It does not describe the legal effect of the decision, as in the case of Article 7(4) above, but only requires the adoption of $a$ decision. If not a decision to amend the Biosafety Protocol, a decision on the specification of the identity and unique identification of living modified organisms will have the same legal status as any other decision of the Conference of the Parties serving as the meeting of the parties to the Biosafety Protocol. It is already doubtful whether decisions of conferences of parties on non-organisational matters are binding on parties, but it is beyond all bounds to argue that treaty obligations can be amended by a simple decision if such consent to be bound by decision is not explicitly provided for in that treaty. ${ }^{8}$

\section{CONCLUSION}

The outcome that a few months of treaty negotiations can have on the development of 'other means' of consent to be bound to a treaty is remarkable. The M\&M Protocol, albeit with due regard for the opinion of the Legal Drafting Group, contains some innovative provisions that, inter alia, enable states parties to express their consent to be bound to a treaty amendment by tacit consent. The

8. See e.g. Art. 2(9.d) of the 1987 Montreal Protocol to the 1985 Vienna Convention on the Protection of the Ozone Layer on Substances That Deplete the Ozone Layer, 26 ILM 1541 (1987); see also Art. 12(6) of the M\&M Protocol that also contains provisions on the notification of the decision to states parties and its entry into force. 
legal quality of the Liability Protocol and the Biosafety Protocol suffered from time constraints and mounting pressures to successfully complete the negotiations. As a result, the Biosafety Protocol contains innovative provisions that provide the Conference of the Parties serving as the meeting of the parties to the Protocol with the option of binding states parties to a treaty amendment against their will. The Liability Protocol follows the traditional amendment procedure of the Basel Convention, but mangles the parties that have to express their consent to be bound in a way that is not free from legal difficulties. Since one innovative provision seems to attract another, it will be interesting to see what will slip into the next multilateral environmental agreement.

René Lefeber 